Turkish Online Journal of Qualitative Inquiry (TOJQI)

Volume 11, Issue 1, January 2020: 85-109

DOI: $10.17569 /$ tojqi.627310

Research Article

\title{
Reflective Peer Feedback in the Practicum: Qualitative and Quantitative Practices
}

\author{
İlknur Yüksel ${ }^{1}$, Banu Çiçek Başaran ${ }^{2}$
}

\begin{abstract}
Professional development for teacher-trainees is commonly viewed as the relationship between a university supervisor, a school mentor and the trainee. The feedback provided by more experienced practitioners is thought to enhance professional development process. On the other hand, peer-feedback can also be used as a means to facilitate teaching practices of pre-service teachers. By receiving and providing feedback, the teacher candidates can also gain a better understanding of their own learning processes. By following a triangulation mixed methods design, this study aims to investigate the peer-feedback practices of 100 pre-service English teachers. The study also examines the relationship between reflective practice and peerfeedback. For the data collection tool, an online rubric scale consisting of forty questions has been used. Data analysis procedure entailed descriptive statistics and coding of the qualitative data. The items in the rubric scale were categorized and the results obtained from quantitative data were compared with findings acquired through qualitative data. The results of the study revealed that the pre-service teachers tend to give high scores $(m=4.37)$ for their peers; although, they provided some criticisms in their comments. The study also showed that, the most problematic areas for the participants were pronunciation of the target language, asking questions, error correction, linking previous lesson and the present one, and using audible voice. The results gained from qualitative analysis indicate that the participants also had difficulties with classroom management, nervousness and cooperation. The findings of the study suggest some fruitful implications to reinforce peer-feedback practices in pre-service teacher education.
\end{abstract}

Keywords: Reflective practice, pre-service English teachers, peer-feedback, professional development.

\footnotetext{
${ }^{1}$ Assist.Prof.Dr., Eskisehir Osmangazi University, Education Faculty, Foreign Language Education, iyukse179@gmail.com, https://orcid.org/0000-0003-1145-6495

2 Res.Asst., Eskisehir Osmangazi University, Education Faculty, Foreign Language Education, bcbasaran@ogu.edu.tr, https://orcid.org/0000-0002-4978-0891
}

Received: 01.10.2019, Accepted: 21.01.2020 


\title{
Öğretmenlik Uygulamasında Yansıtıcı Akran Dönütü: Nitel ve Nicel Uygulamalar
}

\begin{abstract}
$\ddot{O} z$
Öğretmen adaylarının mesleki gelişimi denince akla yaygın olarak üniversiteler ve okullardaki danışmanlar ile öğretmen adayları arasındaki ilişki gelmektedir. Daha deneyimli meslektaşlar tarafından verilen geribildirimin, mesleki gelişimi desteklediği düşünülmektedir. Diğer bir yandan, akran-geribildirimi de hizmet öncesi öğretmen yetiştirmede bir araç olarak kullanılabilir. Geribildirim alarak ve vererek, öğretmen adayları, kendi öğrenme süreçleri hakkında daha iyi çıkarımlarda bulunabilirler. Zenginleştirilmiş karma yöntemden faydalanarak, bu araştırma, 100 hizmet öncesi İngilizce öğretmeninin akran-geribildirimi uygulamalarını incelemeyi amaçlamaktadır. Çalışma, ayrıca, akran-geribildirimi ve yansıtıcı uygulama arasındaki ilişkiyi de incelemeyi hedeflemektedir. Veri toplama aracı olarak, kırk sorudan oluşan çevrimiçi bir anketten yararlanılmıştır. Veri çözümleme süreci betimleyici istatistik ve nitel verilen kodlanmasından oluşmaktadır. Anketteki maddeler önce kategorilere ayrılmıştır. Nicel veriden elde edilen bulgular, nitel veriden alınan sonuçlarla karşılaştırılmıştır. Çalışmanın bulguları hizmet öncesi öğretmenlerin, akranlarına yüksek puanlar verme eğiliminde olduklarını göstermiştir $(\mathrm{m}=4.37)$. Bununla birlikte, nitel olarak sağladıkları veride, gözlemledikleri akranlarına bir takım eleştirilerde de bulunmuşlardır. Bulgular aynı zamanda katılımcıların, hedef dilde telaffuz, sınıfta soru sorma, hata düzeltme, bir önceki dersle ilişki kurma ve anlaşılabilir bir ses tonu kullanma gibi noktalarda sorun yaşadıklarını göstermektedir. Nitel veriden elde edilen bulgularda ise, sınıf yönetimi, tedirginlik ve işbirliği açısından öğretmen adaylarının sorun yaşadığı gözlemlenmiştir. Çalışma, hizmet öncesi öğretmen eğitiminde akran-geribildiriminin kullanılmasına ilişkin bir takım olumlu çıkarımlarda bulunmaktadir.
\end{abstract}

Anahtar kelimeler: Yansıtıcı uygulamalar, hizmet öncesi İngilizce ögretmenleri, akrangeribildirimi, mesleki gelişim. 


\section{Introduction}

The practicum has a pivotal role in teachers' professional development as an induction to their teaching career. In spite of several benefits of the practicum experience on the pre-service teachers (Richards \& Lockhart, 2007), the nature of this process; being evaluated and criticized on their performance in the real life context where they teach and encounter new situations for the first time, can cause several burdens on the pre-service teachers. The feedback that many pre-service teachers receive after teaching practice from the university supervisors and/or mentors is revealed as the main source of negative experience and attitudes of many pre-service teachers (Forbes, 2004). In many countries, the practicum adapts a kind of transmission model in which pre-service teachers receive feedback from university supervisors and experienced mentor teachers on their lesson plans, teaching performance and other components of teaching in post-observation sessions (Nguyen, 2007). Although these post-observation sessions are valuable for pre-service teachers' development (Hyland \& Lo, 2006), the dominant figure of supervisor and the mission of evaluating could limit pre-service teachers as they mostly agree on the feedback without reasoning or reflecting on their performance. Nguyen (2017) defined such model of practicum as 'a process of transferring knowledge and experience from experienced teachers to pre-service teachers' rather than a process of reflective learning by preservice teachers themselves (p. 12).

The literature points out that peer mentoring has been commonly used as a technique for teacher development since it enhances collaboration, reflective teaching, and critical thinking (Nguyen and Ngo, 2017). In other words, teacher training is viewed as a "transformation" process rather than as a "transmission" process (p. 189.) The same study underlines that this process helps coconstruction of knowledge and practice among peers. Through negotiating, inquiry, and conversation, the feedback provided can enhance reflective practice for the professional development of teachers. In other words, it can be inferred that the feedback provided by the peer pre-service teachers may be as beneficial and helpful as feedback given by supervisors and mentor teachers.

On the surface, peer feedback may strike as paradoxical since feedback in teaching practice is commonly linked with the relationship between teacher candidates and the university 
supervisors or mentors at schools. On the other hand, recent studies in the literature refer to teacher training and mentoring to be much more collaborative or collegial relationship rather than the supervisor or mentor feedback (Cornu, 2005). It is believed that peer feedback improves teaching practices, since the use of these feedback routines provides an environment in which the professional communities can offer help and challenge one another to learn new practices, and to change old assumptions, beliefs and practices. Furthermore, for teacher candidates, daily conversations with colleagues or peers along with the classroom experience can be helpful to build links between beliefs and principles (Richards et. al., 2001). Moreover, the peer feedback, collegial cooperation, supports pre-service teachers to develop a sense of support and fellowship while providing them with a chance to express their professional feelings and thoughts as well as receive vocational help. Similarly, peer feedback reduces the chance of isolation and burnout in professional sense since it helps build communication and trust among colleagues (Forbes, 2004). For this reason, peer mentoring is referred to as a reciprocal supportive process in which both pre-service teachers play the role of mentor to each other, providing psychosocial and career-enhancing support (Nguyen, 2017).

The premise of effective feedback either by peers or supervisors or mentors is the way it is provided. The means and method of feedback determines how well the pre-service teachers internalize it and thus how they reflect and develop their teaching practice accordingly. For feedback sessions, there are two common pedagogical practices; the use of analytic rubrics for grading according to the certain indicators and collaborative practices such as collaborative small group discussions with peers and supervisors. The advantages and disadvantages of these common practices have been studied so far from different perspectives in various contexts (e.g. Nguyen \& Ngo, 2017; Yüksel, 2011). However, there is a paucity of the study on the potential use of combination of these two practices: peer feedback through analytic evaluation (Lindahl, Christison \& Tomas, 2019) and reflective feedback. Addressing to this gap, the present study aims to investigate the potential use of peer feedback on analytic rubric supported with reflective feedback within the context of ELT pre-service teachers' education. Through this study, it is attempted to reveal that combining these two practices could help structure the peer feedback and it could provide a practical theoretical base to include the peer into the evaluation process supporting reflection. 


\section{Literature Review}

The literature focused on several aspects of peer feedback such as the benefits of feedback from observers and observed teachers point of views, while some others placed more importance on learning by watching a colleague. Forbes (2004), for instance, studied the effectiveness of a reflective peer feedback model to observe the professional growth of teachers. The results of the study showed that peer feedback serves as a solid support mechanism whereby the teachers can boost their risk taking skills and enhance their professional development process. Along the same lines, Cornu (2005) denoted on the contrary of authority and dominant role of supervisors in traditional feedback type, the peer feedback has an advantage of providing a collaborative relationship based on partnership where neither of the participants holds a position of power over others. By studying the effect of analytic rubric use in peer feedback, Lindahl, Christison and Tomas (2019) revealed that after the use of rubrics, pre-service teachers' abilities to identify quality indicators for L2 lesson planning and delivery were positively influenced. Lindahl et al. (2019) underlined the fact that the knowledge of indicators does not translate into actual implementation of the indicators; however, the first step before implementation is "seeing" and "recognizing" (p. 75). Therefore, it was argued by the same study that the teacher trainers should provide opportunities for trainee teachers to realize, analyze and reflect the indicators of best teaching practices for professional development. These opportunities, of course, include mentor and peer feedback practices. In the same vein, Brown (2001) underlined the benefits of utilizing self and peer assessment that self and peer assessment provides fast evaluation, direct involvement, enhances autonomy and motivation. As noted by several other studies, direct involvement of pre-service teachers in the evaluation process prepares them for the professional environment where they are expected to make judgements about their own teaching practices (Boud \& Falchikov, 2006).

Ratminingsih, Artini, and Padmadewi, (2017) observed that by the help of peer assessment, the participants can learn to give constructive feedback to evaluate themselves and make comparisons between each other's practices. Furthermore, peer feedback can help learners to create a collaborative learning environment where they can practice their assessment and critical thinking skills. Additionally, the peer collaboration can inspire them to learn from one another to develop themselves academically, emotionally and cognitively (Cheng \& Warren, 
2005; Kollar \& Fischer, 2010; Vickerman, 2009;). Based on these; it can be argued that peer feedback is a fruitful technique for evaluation (Ratminingsih et al. 2019). The advantages of utilizing peer feedback are not limited to the aforementioned points alone. Spiller (2012) identified several benefits of using peer feedback in evaluation process: (1) it can promote collaboration among learners to understand the nature of good work, (2) the learners can realize the gaps in their practices and develop a more advanced sense of their own learning process, (3) by giving feedback to their peers, the learners can develop their own analytical thinking skills, (4) receiving feedback from their peers can help them to analyze their practices from a different point of view, (5) peer feedback can diminish the power imbalance between practitioners and learners and it can help the learners to take the responsibility of their own learning process, (6) peer feedback can help create and maintain community of practice, since they become the active participants of the learning process through negotiating the structure of their own learning community (Wenger, 1999).

Additionally, White (2009) concluded that the use of peer assessment showed a significant result in learning process. The study examined peer assessment practice through a questionnaire administered to 55 learners taking Public Speaking in EFL in Japan. The results revealed that the participants had positive beliefs about peer evaluation and this resulted in the enhancement of student learning. Similarly, by carrying out an experimental study, Sun (2015) concluded that peer assessment can have a positive effect on learners' achievement. What's more, peer feedback can provide opportunities for interaction between learners and hence can increase the chances of giving and receiving objective evaluation; their critical thinking skills, and autonomy (Azarnoosh, 2013).

The potential of peer feedback in practicum has been recently realized in Turkish context. Although the effects of peer feedback and peer mentoring have been studied in relation with micro teaching at methodology courses (Koç \& Ilya, 2016), there are limited studies which investigated the peer feedback in teaching practices in actual classrooms during practicum course at $4^{\text {th }}$ year. Out of these limited studies, Göker (2006) examined the effects of peer mentoring on pre-service teachers' self-efficacy beliefs and development of instructional skills. The results indicated that self-efficacy was increased at the end of the term as peer coaching allowed more focus and reflection on action, promoting autonomy and more freedom for the 
pre-service teacher. Yüksel (2011) compared two feedback modes; teacher-mediated and peer feedback to investigate the change in the pre-service teachers' language teaching during their teaching practice. The results showed that peer feedback had a potential to change the teachers' beliefs through critical reflection skills that were fostered as a result of collaboration within the peer group. In spite of promising results of peer feedback on the pre-service teachers' perceptions and performances, there is paucity of the studies and implementations about the peer teaching and mentoring during practicum course. In this study, it is aimed to address to this gap and to examine the peer feedback in comprehensive manner integrating different peer feedback practices.

\section{Methodology}

\section{Research Design}

This study follows a triangulation mixed methods design (Creswell, 2005). This design makes use of both quantitative and qualitative data. It is suggested by Creswell (2005) that the aim of triangulation mixed methods design "is to simultaneously collect both quantitative and qualitative data, merge the data, and use the results to understand a research problem" (p. 514). In this study, the data collection tool included scale items and open ended questions. Through open ended comments, the study aimed to elicit students' responses that would enhance their reflective practices. It is argued that eliciting learners' responses through qualitative tools helps them to think and share their opinions as opposed to only providing scale scores (Creswell, 2005). In this design, both types of data are viewed equally important and they are analyzed to see the similarities and differences between the results of the two types of data (Creswell, 2005).

Following the premise of the triangulation mixed method design, the present study combined both quantitative and qualitative data for each different feedback practice. Through quantitative analysis, the participants' peer assessment on rubric scale was determined while the analysis of participants' written reflective feedback provided the qualitative data of the study. The combination of both quantitative and qualitative analysis revealed the comprehensive view on the potential use of peer feedback in the practicum. 


\section{Research Questions}

The aim of this study is to examine the potential use of combining two different peer feedback practices; peer assessment on analytic rubric and reflective peer feedback. To reveal how these two different approaches could be used; two research questions were addressed:

1. How do the pre-service teachers assess their peers' teaching performance in the practicum?

2. What kind of reflective feedback do they give to their peers in the practicum?

\section{Participants and Research Process}

Criterion sampling among the purposive sampling strategies was applied; including the participants that meet the predetermined criterion according to the research topic and represent the population of the research (Y1ldırım \& Şimşek, 2011). The predetermined criterion for this study is to pass the school experience course and to attend to the teaching practicum course. As a result, 100 senior students in the department of English Language Teaching were included in the study.

The participants had two semesters of teaching practice course (school experience at the $7^{\text {th }}$ term and practicum at the $8^{\text {th }}$ term). This study took place at the $8^{\text {th }}$ semester (last term) of the undergraduate program to which the participants were attending. The pre-service teachers had completed the methodological component and the school experience course of the program before starting the practicum process. During their practicum, the pre-service English teachers were required to submit weekly reports, lesson plans and reflection papers. The length of the practicum was 14 weeks and the participants had to attend the English classes offered at public schools for 6 hours a week. Each participant taught one class hour a week during this process. The participants were asked to observe each other throughout the practicum. Upon completing the practicum, the teacher candidates were invited to fill out the scoring scale as a rubric to evaluate their peers from several aspects and wrote reflective feedback about their friends' performances. 


\section{Data Collection Instruments}

This study utilized a rubric scale as a data collection tool with forty 5-point-scale questions accompanied with forty open ended questions. The scale was developed by one of the researchers. In the development of the scale, the $4^{\text {th }}$ year students attending to practicum, different from the participants of the present study, were asked to write down according to what criteria they want to be evaluated during their practicum. 42 students proposed 150 criteria; the repeated, overlapping and misleading or irrelevant ones were extracted, totally 50 criteria were obtained. After the related literature was reviewed (Bryant, Maarouf, Burcham \& Greer, 2011; Pennington \& Young, 1991 and sample rubrics on teaching performances were examined, the final version of the rubric scale for teacher performance was piloted with 42 participants as well as 4 supervisors of these students. The results indicated that the developed analytical scale as a rubric for teaching performance is reliable with .72 coefficient value.

For the present study, this developed scale was given to 100 participants and they were asked to give a score to their peers' from 1 to 5 ((1) unsatisfactory, (2) satisfactory, (3) average, (4) above average, and (5) excellent.). The items in the scale were categorized according to the domains of teaching: (a) preparation, (b) presentation, (c) performance, (d) personal characteristics, and (e) teacher-student interaction. Each group had different list of items to be scored. After scoring, the participants were to write their reflective feedback for each of the scale items. At the end of the scale, the participants were asked to write a reflective feedback for the overall evaluation of the observed peer. The data collection tool was administered online through survey monkey.

\section{Data Analysis}

For the present study, both qualitative and quantitative data were collected together, and the descriptive statistics were used to analyze the quantitative data. The mean scores for each of the items were calculated separately. Lastly, each of the categories were analyzed and the weighted mean scores were calculated for comparison.

In addition to the scores that each participant gave on the analytic rubric given in the scale, the participants were expected to provide comments for their peers for each of the items. The 
participants were encouraged to write reflective feedback for each item. The participants had a training on how to give reflective feedback in the methodology courses before the practicum. This reflective feedback constituted the qualitative data of the study. Applying the content analysis, each of the item-comments was grouped according to the aforementioned categories (i.e. preparation, presentation, performance, personal characteristics and teacher-student interaction) and then used to compare the results obtained from the quantitative data. For the last item, overall evaluation section, the evaluations of pre-service teachers were coded and then classified into themes for further analysis and comparison.

\section{Findings}

The quantitative data was analyzed firstly and the peer assessment on the analytic rubric was presented for each category with the descriptive findings, then the qualitative data was discussed and exemplified with some quotations. The findings of the study are first presented referring to the five categories, questioning the domains of teaching performances as the foci of the study. In that way, it was firstly aimed to combine the participants' qualitative and quantitative feedback to their peers so that two different practices of peer feedback will be presented under the same category. Then, the qualitative analysis of overall reflective feedback of the participants is given.

\section{Preparation}

In this part of the rubric, the participants were asked to score items related with the preparation part of teaching. In this part there were 4 items to assess the observed peers. The weighted mean score of this category is 4.36 out of 5 .

Majority of the participants (65\%) think that their peers were well-prepared for the lesson; the students were warmed-up before the lesson (64\%), and the goals of the lesson were clear $(64 \%)$. When it comes to reviewing the previous topic and linking it to the current one, the participants provided mixed answers. The mean for this is the lowest in this group $(m=3.99)$. It can be argued that the participants think that their peers were somewhat unsuccessful in creating a link 
between previous and new topics. Overall, the pre-service teachers were satisfied with their peers' preparation for teaching. This may stem from the fact that the pre-service teachers were required to submit lesson plans on weekly basis. Nevertheless, not all the participants agree that the observed peers were in fact prepared for the lesson. The reflective feedback on teacher preparation category contained the themes of lesson organization, activities and materials. Although the participants scored high for this item on the rubric, they gave mixed feedback comments for their peers' preparation. There were very positive comments as well as some criticism.

As for the lowest scored item in this group, linking the previous topic with the present one $(m=3.99)$, the participants focused on the frequency aspect. Several of the reflective feedback mentioned that their peers did not always link the previous and current topic during their lessons.

"The teacher was very careful about making connections between previous lesson from time to time". (P9) [sic]

"When the topic was hard or students didn't understand the previous topic, she reviewed the previous topic". (P61)

Overall, the teacher candidates evaluated their peers to be well-prepared with some minor setbacks they mentioned in their comments. It can be observed that the comments and the scores they provided for this section of the rubric were somewhat in line with each other.

\section{Presentation}

In this part, the participants were to score their peers based on their actual teaching performances. The eleven criteria in this section were about the teaching procedure that the pre-service teachers had to complete. The overall score for this group is 4.40 out of 5 .

Similar to the preparation section, the participants gave high scores to their peers for the presentation stage. The highest scored item was related with age appropriateness of the activities used in the lesson $(m=4,67)$; while the lowest scored item was about the use of instructional aids such as instruction checking questions (ICQs) and asking questions $(\mathrm{m}=4,10)$. Overall, again, the participants were pleased with their peers' teaching performance on the rubric. 
When it comes to the comments they provided for the presentation part, again, similar results can be observed. The participants generally wrote positive comments for their peers' presentation. For example, they stated that their peers were effective in presenting the topic and that the activities were appropriate for the class level. For lesson sequence and organization, the pre-service teachers provided comments that were in line with the rubric scores $(\mathrm{m}=4.42)$. They stated that the observed peer had well sequenced and planned lessons. Along the same lines, for lesson pace, the comments they provided were generally positive. On the other hand, there were few instances when the participants reported time management problems due to unexpected issues in the lesson or classroom management. The teacher candidates also wrote comments for giving instructions during the lesson. Generally, their comments bore positive statements about this item; however, a few of the participants also mentioned some problems related with instructions. They mentioned that the instructions were confusing and/or not clear. Some of them stated that getting used to giving instructions took time while others said that the nature of the activity (group/individual) or the language level of the students were the factors that made giving instructions difficult for them.

"Instructions were clear and concise but they weren't clear all the time, both of us sometimes had difficulty in giving the instructions". (P6) [sic]

'Because of students' levels, instructions couldn't be arranged appropriately. So, sometimes different techniques (body language, showing, giving example, clues) for instructions didn't work well'”. (P49) [sic]

"Especially when she prepared a group work, she had some difficulties to give instructions. By drawing on the board, showing an example are good for her (it was also difficult for me)". (P78) [sic]

The highest scored item in this part of the rubric was about the activity appropriateness. Majority of the participants think that the activities used in the lessons were age $(\mathrm{m}=4.67)$ and ability $(m=4.62)$ appropriate. The comments they wrote for these two items were in line with the scores they gave. The teacher candidates think that the activities their peers used during their lessons were appropriate for the student profile. They observed that their peers were successful in bringing activities that will attract the students' attention and also that are suitable. On the other hand, the participants mentioned few times where the activities were above the students' current level of language and due to this reason the students could not finish them. 
For the last and lowest scored item of this section of the rubric, effective use of instructional aids, $(\mathrm{m}=4.10)$, very few of the participants commented. They mentioned either that their peers were successful at using ICQs or that they failed to do so and wrote some suggestions.

"For some tasks, she used ICQs it worked effectively". (P3)

"Instruction checking is a big problem for her. I don't know. Students are too naughty so that she forgets the checking. She should use more easier sentences when giving instruction and also for checking”. (P48) [sic]

\section{Performance}

In this part of the rubric, the participants were asked to evaluate their peers with regards to their performances as teachers. The mean for this part is found to be 4.33 .

In this part of the rubric, the results revealed that the highest scored items were moving around the classroom and maintaining eye-contact with the students $(m=4.54)$ and using examples and illustrations effectively $(\mathrm{m}=4.54)$. They are followed by using positive reinforcements $(\mathrm{m}=$ 4.49) and using drills and exercises effectively $(m=4.48)$. Interestingly, the lowest scored item was related with error correction policy $(m=4)$ in this section of the rubric.

Upon analyzing the comments provided for this section, it can be seen that the students showed similar tendency. They tend to write comments that are in line with the scores they gave. For example for using a variety of activities in the class $(m=4.35)$ they mentioned that their peers successfully selected activities and exercises for most of the time. Similarly for their peers' adapting skills $(\mathrm{m}=4.21)$ they commented that the observed teacher candidate was able to overcome unanticipated problems for most of the time. Some students brought up some issues with unanticipated problems as well. They mentioned that their peers were not able to cope with unexpected problems due to being inexperienced or not knowledgeable enough.

"When there was a problem about the smartboard, he was stuck but it is because of lack of knowledge and training. Also, when the subject was broken and students started to talk about something else, he tried to do go back to lesson and ignore the environment of the class". (P58) [sic]

"She looked shocked when she was in a situation that she would not anticipate". (P63) [sic] 
For making eye-contact with the students and moving around the class during lessons, the participants gave highest score of this section in the rubric $(m=4.54)$. In line with the scores in rubric, in their comments, they mentioned that at the beginning their peers were somewhat reluctant to move around the class but as the time went by, they got used to the class and they improved themselves. Others pointed out that their peers established eye contact with the students and used their body language.

The lowest scored item on this section of the rubric was having an error correction policy $(m=4.0)$. In their comments they mentioned that the observed participant missed majority of the errors or the peer was not able to "catch" the errors all the time. They also mentioned the type of error correction they utilized. They preferred direct, indirect, and peer error correction in their lessons.

\footnotetext{
"Yes, first she repeated the question one more time and asked like "A or B? Please think about it one more time”. (P28) [sic]

"He might sometimes miss the error, but mostly he caught and told the true ones". (P39) [sic]

"When students answer the questions and some of them make any mistake, her explanations weren't clear”. (P50) [sic]

"Sometimes she realized the mistakes of students and she corrected but sometimes she didn't realized". (P83) [sic]
}

The last item of this part of the scale was about classroom management $(m=4.15)$. For this one, although the score can be considered as rather high, the comments revealed that the participants, in fact, criticized their peers' classroom management skills. They wrote that the observed pre-service teachers needed to improve themselves by monitoring the students and being more involving. Few of them also stated that they found their peers' classroom management skills effective.

"The students were passive in the lessons in general but they spoke about irrelevant topics all the time. However, the teacher controlled the class. (P33)

“We were both not good at classroom management”. (P40) 
"She had problems on controlling the class but she learnt thanks to her mistake. For example, she gave the materials (mask) before instruction. And she lost the control because the students focused on the mask. Then she never did the same mistake”. (P67) [sic]

The reflective feedback indicated that the participants could evaluate the performance more critically when they had chance to think upon it.

\section{Personal Characteristics}

This part of the rubric had items about the observed participants' characteristics as teachers (use of voice, facial expressions, fluent English, enthusiasm, and so on). There are six items in this part of the rubric and the mean is found to be 4.22 .

The highest scored item in personal characteristics part was about the patience of the teacher in eliciting answers from the students $(\mathrm{m}=4.40)$. The participants stated that their peers waited for students to give the correct answers rather than providing the answers themselves. On the other hand, the lowest score of this section belongs to the item about teachers' voices $(\mathrm{m}=$ 3.96). In their comments the participants wrote that their peers were not audible during their lessons at the beginning of the term; however, as the time passed some of them improved themselves in terms of this issue. Some pre-service teachers focused on the tone of voice rather than loudness.

"When there was an activity, there was a problem for back-sitters to hear him. He could have used his voice more effectively. Except this, he used his voice well". (P37) [sic]

"Her voice was audible everywhere in the classroom. But she should change tone of her voice because sometimes she is talking as if shouting”. (P40) [sic]

In the same vein, the participants evaluated their peers' pronunciation in the target language as natural $(m=4.13)$. Again, the comments displayed different ends of a continuum. Some comments stated that the pronunciation of their peers was very good, while some others pointed out that there were serious problems.

"I don't want even comment about it. She doesn't care about her pronunciation and our mentor warned her many times. I may make mistakes too, this is okey. But how 
can a pre service teacher who will almost graduate makes that much simple pronunciation mistakes? I don't think that she checks words' pronunciations before coming school”. (P49) [sic]

"We were studying our pronunciation from online dictionaries with voice if it's a vocabulary lesson. She was studying on them”. (P94) [sic]

\section{Teacher-Student Interaction}

In the last part of the rubric, the participants were expected to evaluate their peers in terms of teacher-student interaction (involving students, questioning, encouraging, being friendly and so on). There were seven items in this part of the rubric and the mean score is 4.54 .

With 4.66 mean, treating students with respect and fairly was the highest scored item of this part of the rubric, while the lowest score belonged to being able to involve the students in the lesson $(m=4.44)$. Treating students fairly and with respect $(m=4.66)$ was another item to be observed by the participants. All of the comments mentioned that the trainee was fair and respectful towards the students. Similarly, for the next item, encouraging the students $(m=4.6)$, all the comments bore positive remarks about the observed peers. For being aware of individual and group needs $(m=4.5)$, the participants commented that the trainee used group work and individual activities, they arranged the exercises and the materials based on the level of the students.

For encouraging participation of the students during the lesson $(m=4.45)$, the pre-service teacher stated that the observed peers were successful in general. They mentioned that the trainee used praise words and tried to include all the students in the lessons. There were few instances where the trainee was deemed to be unsuccessful.

"He tried to encourage all of the students but he needed to control the class' environment more. It was also because of the class, almost the half of the students did not willing to attempt”. (P47) [sic]

Finally, the last item to be scored on the rubric was about teachers' ability to create a friendly and fun atmosphere in the classroom $(\mathrm{m}=4.49)$. The participants wrote that the trainees were 
humorous during the lesson, they utilized songs and music, and they included creative activities for the students.

\section{Comparison of Category Scores}

Examining the items in the whole rubric, it is observed that the highest score belongs to the item about activities being appropriate to the age of the students $(m=4.67)$ in the presentation part; while the lowest scoring item is about using audible voice $(\mathrm{m}=3.96)$ in personal characteristics part. The highest and the lowest scored five items of the whole rubric can be seen from Table 1 below. Based on these scores, it can be argued that the highest scored items are least problematic for the trainees while the lowest scored items are the most problematic for them.

\section{Table 1}

Top and Bottom Five Items of the Rubric

\begin{tabular}{|c|c|c|}
\hline & Items & Weighted Mean \\
\hline \multirow{5}{*}{ 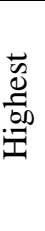 } & The activities were appropriate to the age of the students. & 4.67 \\
\hline & The students were treated fairly and with respect. & 4.66 \\
\hline & The topics were presented at the students' level of comprehension. & 4.64 \\
\hline & The class felt free to ask questions, to disagree, or to express their own ideas. & 4.62 \\
\hline & The activities were appropriate to the ability of the students. & 4.62 \\
\hline \multirow{6}{*}{$\begin{array}{l}\overrightarrow{\ddot{D}} \\
0 \\
\vdots \\
0 \\
=\end{array}$} & The pre-service teacher's pronunciation was natural. & 4.13 \\
\hline & Instructional aids, such as ICQs and asking students were effectively used. & 4.10 \\
\hline & The pre-service teacher had an appropriate error-correction policy. & 4.00 \\
\hline & The teacher reviewed the previous topic and linked it to the present one. & 3.99 \\
\hline & The teacher's voice was audible everywhere in the classroom. & 3.96 \\
\hline & OVERALL RUBRIC SCORE & 4.37 \\
\hline
\end{tabular}

Similarly, upon comparing the mean score of the parts of the rubric, it is observed that teacherstudent interaction part has the highest mean score of the whole rubric $(\mathrm{m}=4.54)$. Although, overall, the participants gave high scores to their peers $(\mathrm{m}=4.37)$, it can be deduced that the participants found teacher-student interaction in the observed lessons was more successful than all the other four groups of criteria. Summary of the mean scores for each category can be seen from Table 2 below. Again, based on the mean scores, the most problematic part for the trainees 
was personal characteristics $(m=4.22)$. As the reflective feedback provided by the participants their peers needed to develop many manners.

Table 2

Summary of the Mean Scores of Group Items

\begin{tabular}{lc}
\hline Groups & Weighted Mean \\
\hline A. Preparation & 4.36 \\
B. Presentation & 4.40 \\
C. Performance & 4.33 \\
D. Personal Characteristics & 4.22 \\
E. Teacher-Student Interaction & 4.54 \\
Overall Rubric Score & 4.37 \\
\hline
\end{tabular}

\section{Overall Evaluation}

For further evaluation and to triangulate the results of the quantitative data, the participants were asked to write a reflective feedback evaluating the overall evaluation of their peers' performances. Out of 100 participants 92 provided comments for their peers. While the "good" comments revolve around being successful, well-prepared, friendly, enthusiastic, creative, and bringing good materials and activities to the lessons; the criticisms are mainly about classroom management, not using audible voice, not following the stages of a lesson, having fluency and accuracy problems while speaking in the target language, being nervous, and uncooperative. When criticizing the participants followed certain patterns, such as opening with a positive remark and then mentioning the negative sides or pointing out the problem and then making some suggestions for improvement. Comparing the results obtained from the rubric and the open ended question, it is seen that there are some similarities and some differences. For example material appropriateness was the common point for "good" aspects of the trainees while using an audible voice and speaking in the target language were the common points for" bad" aspects of the observed trainees' teaching.

"She was well prepared for every class. She also did her best for teaching. However, while me, my partners and even our mentor was teaching and lecturing, she always talked with students. There is always noise in the classrooms, this was one of the our problems. In addition to this problem, she also talked with students instead of keeping them silent. Also, she behaved students as a friend. As a result 
of this behaviour, I and my partners had some difficulties to manage the classroom during the class time". (P9) [sic]

"She prepared good materials for her lessons. She was effective to design group works and she was good at developing her students' interaction in the class. She has a good relationship with her students but I suggest her to avoid personal talks in the class. She loses time. She should develop her classroom management". (P22) [sic]

As can be seen from the comments above, the pre-service teachers mention "good and bad" aspects of the observed teacher together. The participants started with positive comments, mentioned the problematic aspects and then closed with a positive remark.

"She did her best I think. Everybody will improve himself/herself in time. She was good at speaking, using true words during the lessons and pronunciation. She prepared materials but she mostly used worksheet and board. On the other hand, our students were young learners. She did not use interactive and movable teaching materials enough. Both of us were bad at classroom management. Her voice power need to be improved. She gave her instructions before her lesson mostly. However, her instructions was not successful. She was relaxer than me in an unanticipated situation. However, she did not prepared a plan $B$ for her lessons at all. She was a good teacher in general. " (P40) [sic]

"Generally, she was well-prepared in terms of materials and other supplies for the lesson. Her attitude toward students was respectful and kind. However, she is a bit shy to students sometimes. She can be more active in lessons and willing to communicate with students. in some lessons, she couldn't manage the time and I was stuck in a difficult situation to complete my lesson. Generally, she prepared and used materials well but I think she should be more careful about managing/controlling the class." (P62) [sic]

After providing specific examples and cases to root their criticisms, the participants close their comments with positive statements or use some at the beginning. By providing feedback on their peers' teaching practice, the pre-service teachers also reflect back on their own teaching as well. P40 focused on some problems and wrote that both herself and the observed peer need to improve their classroom management skills. P62 (above) mentioned that due to their peers' problems, they also experienced some difficulties. Similarly, by providing a comment, P70 (below) argues that a teacher should be aware of her/his weaknesses and strengths in order to develop professionally. These statements show that peer-feedback can also serve as a means for reflective practice. On the other hand, few of the participants focused only on the negative aspects of the observed pre-service teacher. 
"If a person wants to be a teacher, he/she should be aware of students' needs. She should know her abilities or her skills which need to be improved. She was so quiet in the class even while teaching. When she had a problem in the class, she didn't do anything to solve it. She just smiled and continued her lesson like nothing happened. I think most of the time she didn't know what to do in class. She didn't use her creativity while teaching or preparing materials. She didn't good at managing the classroom. Her body language, her mimes, her voice and all of the things about her never impressed me through 10 weeks. I hope that she improve her teaching skills". (P70) [sic]

As the example showed the participants sometimes felt free to criticize but as appropriate to nature of reflective feedback, they tend to reflect upon the reasons for their criticism and suggest the solutions.

\section{Discussion and Conclusion}

This study examined the potential use of combining two different peer feedback practices; structured analytic peer assessment and reflective peer feedback. Through analytic rubric, the pre-service teachers engaged in assessing their peers and they got familiarized with the criteria to evaluate the teaching performances. This increased their awareness and they received necessary guidance to reflect on the essential domains of teaching performance. Encouraging them to write reflective feedback in open-ended statements on each evaluation criteria in the rubric, the participants practiced to give feedback on the certain points. So, they improved to give focused reflective feedback. As the results indicated while assessing their peers on the rubric, most of them gave optimistic, high scores. So, the participants were mostly subjective and supportive. This results comply with the studies of and Sun (2015) and Azarnoosh (2003). In spite of some bias in the peer assessment, it fosters critical thinking skills and learning achievements, besides it could guide them how to give reflective feedback as Ratminingsih et al (2017) suggested. This was observed in the participants' reflective feedback on each criteria and overall evaluation. Particularly, in the overall evaluation, the participants' feedback was more focused and they reflected on their peers' and their own performances criticizing with clear rationales and suggesting the better ways. This is the desired manner for reflective peer feedback as Nguyen and Ngo (2017) stated. Thus, it could be claimed that combination of 
analytic and reflective peer feedback fostered reflection and provided more opportunities to evaluate their own practice, but also enhances their professional knowledge.

Additionally, the results indicated that providing evaluation criteria and categories for evaluation eased the participants' feedback. Rather than limiting the feedback, it enriched the content. As Lindahl et al. (2019), as the pre-service teachers "realize" the indicators of the best teaching practice, they become more reflective and they touch on more points in their feedback. As the qualitative analysis showed that the participants mentioned many different themes for each category and they made sense of even the same themes according to different categories. For instance, they reflected upon the materials under the categories of both preparation and presentation but they evaluated it from different perspectives regarding the category.

As they practiced the reflective feedback for each item referring the basic indicators for "best" teaching practice, they became more component while giving the last feedback at the overall evaluation. In a way that, they included both positive and supportive but at the same time they had negative feedback criticizing both the peers and themselves. It was observed that they reflected on their performance and they either suggested the better way or they claimed they would adapt the same way that the peer did.

To conclude, the results of this study revealed that the peers could provide reflective and to the point feedback as long as they have a guidance including the indicators for the evaluation. The quality of peer mentoring and feedback could enhance as the pre-service teachers become aware of the cover or focus of their feedback. Combining both qualitative and quantitative methods of peer feedback, the quality and focus of feedback seemed to improve and it became reflective in nature for both their peers' and their professional development.

\section{Suggestions}

This study revealed that the pre-service teachers could give reflective feedback to foster both their peers' and their own professional development. Yet a guidance as provided in an analytic rubric format could lead more focused and structured feedback. This study was designed to present the potential use of combination of qualitative reflective peer feedback and quantitative 
analytic peer assessment. Although this study consisted of a purposeful sample and the results could not be generalized, this study could inspire other studies on peer feedback and how to structure peer feedback sessions. Moreover, the results of this study could be supported and improved with the forthcoming studies on the pre-service teachers' development after such peer feedback practices. 


\section{References}

Azarnoosh, M. (2013). Peer assessment in an EFL context: Attitudes and friendship bias. Language Testing in Asia, 3(11), pp. 1-10.

Boud, D., \& Falchikov, N. (2006). Aligning assessment with long-term learning. Assessment and Evaluation in Higher Education, 31(4), pp. 399-413.

Brown, H.D. (2001). Teaching by principles: An interactive approach to language pedagogy. New York: Addison Wesley Longman, Inc.

Bryant, C.L., Maarouf, S., Burcham, J., \& Greer, D. (2016). The examination of a teacher candidate assessment rubric: A confirmatory factor analysis. Teaching and Teacher Education, 57, 79-96. doi: 10.1016/j.tate.2016.03.012

Cheng, W., \& Warren, M. (2005). Peer assessment of language proficiency, Language Testing, 22(3), pp. 93-121.

Cornu, R.L. (2005). Peer mentoring: Engaging pre-service teachers in mentoring one another. Mentoring and Tutoring, 13(3). pp. 355-366.

Creswell, J.W. (2005). Educational research: Planning, conducting, and evaluating quantitative and qualitative research. Upper Saddle River, NJ: Pearson.

Forbes, C.T. (2004). Peer mentoring in the development of beginning secondary science teachers: Three case studies. Mentoring and Tutoring, 12(2), pp. 219-239.

Göker, S.D. (2006). Impact of peer coaching on self-efficacy and instructional skills in TEFL teacher education. System, 34, 239-254.

Koç, B. \& Ilya, A. (2016). Exploring pre-service language teachers' perceptions and actual practices of giving feedback in micro-teaching. Procedia - Social and Behavioral Sciences 232. 421-429

Kollar, I., \& Fischer, F., (2010). Peer assessment as collaborative learning: A cognitive perspective. Learning and Instruction 20(4), pp. 344-348.

Lindahl, K., Christison, M., \& Tomas, Z. (2019). The impact of rubric use on peer feedback tasks in a TESOL program, Journal of Second Language Teaching \& Research, 7(1), pp. 26-55. 
Nguyen, H.T.M. (2017). Models of mentoring in language teacher education. Switzerland: Springer.

Nguyen, H.T.M, \& Ngo, N.T.H. (2017). Learning to reflect through peer mentoring in a TESOL practicum, ELT Journal Volume 72(2), pp. 187-198.

Pennington, M.C., \& Young, A.L. (1991). Procedures and instruments for faculty evaluation in ESL. In M.C. Pennington (Ed.), Building better English language programs: Perspectives on evaluation in ESL (pp. 191-205). Washington, D.C.: NAFSA: Association of International Educators.

Ratminingsih, N.M., Artini, L.P., \& Padmadewi, N.N. (2017). Incorporating Self and Peer Assessment in Reflective Teaching Practices. International Journal of Instruction, 10(4), pp.165-184.

Richards J.C., \& Lockhart C. (2007). Reflective teaching in second language classrooms. New York: CUP.

Spiller, D. (2012). Assessment matters: Self-assessment and peer assessment. Retrieved September 30, 2019, from http://cei.ust.hk/files/public/assessment_matters_selfassessment_peer_assessment.pdf.

Sun, D.L., Harris, N., Walther, G., \& Baiocchi, M. (2015). Peer assessment enhances student learning: The results of a matched randomized crossover experiment in a college statistics class. PLoS One, 10(12), e0143177. doi: https://doi.org/10.1371/journal.pone.0143177.

Vickerman, P. (2009). Student perspectives on formative peer assessment: an attempt to deepen learning? Assessment \& Evaluation in Higher Education, 34(2), pp.221-230.

Yıldırım, A. \& Şimşek, H. (2011). Nitel araştırma yöntemleri [Qualitative research methods]. Ankara: Seçkin Yayıncılık.

Yuksel, İ. (2011). The Effects of Post-observational Feedback Modes on Teaching Beliefs: Peer vs. Teacher-Mediated Feedback. Turkish Online Journal of Qualitative Inquiry, 2(1), 38-56.

Wenger, E. (1999). Communities of practice: Learning, meaning, and identity. Cambridge University Press. 
İlknur Yüksel, Banu Çiçek Başaran

White, E. (2009). Student perspectives of peer assessment for learning in a public speaking course. Asian EFL Journal - Professional Teaching Articles, 33(1), 1-36. 